\title{
PENGABDIAN INTERNASIONAL BERBAGI ILMU SESUAI BIDANG KEPAKARAN TENTANG VAKSINASI COVID DAN HPV
}

\author{
(vanna Beru Brahmana1), Farindira Vesti Rahmasari'1) \\ 1)Bagian Obstetri \& Ginekologi, Program Studi Pendidikan Dokter, Fakultas Kedokteran \& IImu Kesehatan, \\ Universitas Muhammadiyah Yogyakarta, Yogyakarta, Indonesia \\ Corresponding author : Ivanna Beru Brahmana \\ E-mail : ivanna.beru.brahmana@gmail.com
}

Diterima 18 Oktober 2021, Direvisi 27 Oktober 2021, Disetujui 28 Oktober 2021

\begin{abstract}
ABSTRAK
Latar belakang: Kondisi pandemi saat ini memberikan kemudahan diadakan pertemuan antarnegara melalui webinar. Beragamnya kepakaran mahasiswa Indonesia yang menempuh pendidikan di Thailand memungkinkan saling bertukar ilmu dengan para pakar di Fakultas Kedokteran dan IImu Kesehatan Universitas Muhammadiyah Yogyakarta (FKIK UMY). Selain saling bertukar pengetahuan dan pengalaman, sekaligus pelepas rindu kampung halaman. Tema yang dipilih merupakan trending topic tentang vaksinasi, sekaligus mengupas tentang kesehatan reproduksi, yaitu: Vaksinasi Covid dan HPV. Tujuan: Mengadakan pengabdian internasional melalui webinar antara FKIK UMY dan PERMITHA (perkumpulan mahasiswa Indonesia di Thailand) untuk meningkatkan pemahaman tentang vaksinasi Covid-19 dan HPV. Metode: sosialisasi tentang vaksinasi Covid-19 dan HPV oleh 4 dosen FKIK UMY melalui webinar, dengan peserta mahasiswa, dosen, masyarakat umum dari Indonesia dan mahasiswa Indonesia yang berada di Thailand. Tanya jawab dan diskusi dilakukan setelah penyampaian materi. Kemanfaatan pengabdian ini disampaikan oleh peserta berdasarkan pertanyaan yang disampaikan moderator. Hasil: Pengabdian internasional dihadiri oleh 60 peserta dari Indonesia dan Thailand. Antusiasme peserta tampak dari 13 pertanyaan yang diajukan. Pengabdian internasional ini dirasakan memberikan kemanfaatan yang tinggi, efektif sebagai ajang berbagi ilmu, terjalin silaturahmi sekaligus pelepas rindu kampung halaman. Peningkatan pengetahuan peserta dinilai dengan terjawabnya semua pertanyaan yang diajukan peserta dan peserta menyatakan puas dengan jawaan yang diberikan. Dengan demikian pemahaman peserta setelah webinar mengalami peningkatan dibandingkan sebelum kegiatan. Kesimpulan: Pengabdian internasional yang diisi oleh para pakar di bidangnya banyak memberikan kemanfaatan bagi seluruh peserta, dan mengharapkan pengabdian internasional bisa berkelanjutan.
\end{abstract}

Kata kunci: Covid-19; HPV; pengabdian internasional.

\begin{abstract}
Background: Webinar becomes the only option to held a meeting between countries in this pandemic. The diversity of expertise of Indonesian students studying in Thailand allows the exchange of knowledge with experts at the Medical Faculty and Health Sciences, Universitas Muhammadiyah Yogyakarta (FKIK UMY). In addition to exchanging knowledge and experience, as well as releasing homesickness. The chosen theme is a trending topic about vaccination, as well as discussing reproductive health, so the topic: Covid and HPV vaccinations was raised. Objective: To conduct international service through a webinar between FKIK UMY and PERMITHA (Indonesian student association in Thailand) to increase understanding about Covid-19 and HPV vaccination. Methods: providing information about Covid-19 and HPV vaccinations by four FKIK UMY lecturers through a webinar, with students, lecturers, the general public from Indonesia and Indonesian students in Thailand participating. Questions and answers and discussions were held after the presentation. The benefits of this service were conveyed by participants based on questions submitted by the moderator. Result: The international service was attended by 60 participants from Indonesia and Thailand. The enthusiasm of the participants can be seen from the 13 questions asked. This international service is felt to provide high benefits, is effective as a place to share knowledge, establish friendship as well as release homesickness. The increasing of knowledge was marked by answered all of questions and satisfying all of participants. It means understanding of participants after webinar was higher than before. Conclusion: International service that is filled by experts in their fields provides many benefits for all participants, and we hope that international service can be sustainable.
\end{abstract}

Keywords: Covid-19; HPV; international service. 


\section{PENDAHULUAN}

Masyarakat yang terkonfirmasi positif Covid-19 terus bertambah, bahkan beberapa minggu terakhir menunjukkan peningkatan yang tajam. Upaya pencegahan penularan Covid-19 dengan protokol kesehatan (prokes) saja tidak cukup. Diperlukan tindakan yang lebih adekuat yaitu dengan pemberian vaksinasi Covid-19. Apa dan bagaimana vaksin Covid-19, amankah diberikan, bagaimana dengan penderita komorbid, menjadi suatu bahasan yang sangat menarik. Pemberian vaksinasi Covid-19 mempunyai tujuan mengurangi penularan Covid-19, menurunkan angka kesakitan dan kematian yang disebabkan oleh Covid-19, mencapai kekebalan kelompok di masyarakat (herd immunity) dan melindungi masyarakat dari penyakit Covid-19, agar tetap produktif secara sosial dan ekonomi. Dipandang dari sisi ekonomi, maka upaya pencegahan dengan vaksinasi ini akan jauh lebih hemat bila dibandingkan dengan upaya pengobatan (Kemenkes RI Dirjen P2P, 2020).

Jumlah kebutuhan vaksin Covid-19 di Indonesia diperkirakan mencapai 181,5 juta jiwa. Jumlah tersebut diperinci dalam dua gelombang. Gelombang pertama adalah periode Januari-April 2021, yang terdiri dari: 1,3 juta untuk tenaga kesehatan, 17,4 juta untuk petugas publik, dan 21,5 juta untuk lansia. Gelombang kedua adalah periode April 2021 Maret 2022, yang terdiri dari: 63,9 juta masyarakat rentan dan 77,4 juta masyarakat lainnya (Ma'ruf, 2020).

Berkesinambungan dengan kesehatan reproduksi pada wanita, yang juga sedang menggalakkan vaksinasi HPV sebagai upaya pencegahan primer kanker serviks. Pengabdian dengan pemberian penyuluhan tentang pentingnya Pap smear dan pelaksanaan pemeriksaan Pap smear sebagai upaya pencegahan sekunder terhadap kanker serviks juga dilakukan di lingkungan internal FKIK UMY. Kegiatan tersebut diikuti dengan pelaksanaan vaksinasi HPV pada dosen wanita dan putrinya (Brahmana, 2021).

$$
\text { PERMITHA sebagai suatu }
$$

perkumpulan mahasiswa Indonesia di Thailand memandang perlu untuk bisa saling berbagi ilmu dengan para dosen Fakultas Kedokteran dan Ilmu Kesehatan, Universitas Muhammadiyah Yogyakarta (FKIK UMY). Dengan berbagi ilmu terjadi kesibukan tersendiri yang menyenangkan karena adanya komunikasi. Di masa pandemi ini, pelajar yang disibukkan dengan penelitian berisiko mengalami depresi. Risiko depresi tersbut menurun apabila individu tersebut menyibukkan diri dengan kegiatan lain di sekolah (Ustun,
2021). Adanya komunikasi antara pelajar Thailand dengan yang berada di Indonesia akan mempererat rasa persaudaraan dan tidak merasa sendiri, terlebih di masa pandemi ini. Kecenderungan depresi bisa meningkat pada individu yang merasa seorang diri (Fisher and Stocker, 2020).

Informasi tentang vaksin Covid-19 di era pandemi ini dan vaksin HPV dari sisi kesehatan reproduksi perempuan dipandang perlu untuk dibahas, sehingga para mahasiswa di Thailand maupun Indonesia akan mendapatkan pencerahan tentang topik yang saat ini sedang hangat dibahas. Banyaknya mahasiswa Indonesia di sana, memberikan kontribusi banyak kepakaran dari berbagai disiplin ilmu. Tentu sangat disayangkan kalau banyak keilmuwan ini tidak saling membuka diri dan berbagi. Kondisi pandemi yang tengah terjadi memberikan satu hikmah dengan peluang berbagi ilmu melalui webinar. Metode webinar juga digunakan dalam pengabdian di Jakarta (Nadilla and Zebua, 2020). Dengan kegiatan pengabdian ini akan memberikan kesibukan tersendiri bagi para panitia, narasumber, dan peserta. Dengan berkegiatan seperti ini akan meningkatkan aktifitas, walau tidak harus berkerumun. Aktifitas fisik yang lebih banyak akan menurunkan risiko depresi (Alsharji, 2020).

Hal ini menimbulkan ide untuk dilakukannya pengabdian internasional dengan menggali pengetahuan dari banyak pakar untuk saling bertukar keilmuwan. Ide ini disambut baik oleh kebanyakan anggota PERMITHA dan civitas akademika FKIK UMY. Tujuan pengabdian adalah untuk meningkatkan pemahaman tentang vaksinasi Covid-19 dan HPV, dengan cara bertukar pengetahuan dan pengalaman dari banyak kepakaran dari FKIK UMY dan PERMITHA melalui webinar. Dengan adanya pemahaman ini nantinya diharapkan peserta tidak menerima berita hoax tentang vaksinasi Covid-19. Salah satu hasil penelusuran berita tentang vaksinasi Covid-19 didapatkan 58 judul berita, di mana hanya 13 judul berita yang relevan (Rahayu, 2021).

\section{METODE}

Pengabdian berjudul: "HPV and Covid19 Vaccination: when we can start doing pap smear screening, how to self screen for cervical cancer also urgency and regulation of Covid-19 Vaccination" telah terlaksana dengan lancar pada Hari Sabtu, 5 Juni 2021, pukul 13.0015.00 WIB.

Pengabdian internasional melalui beberapa tahapan, yaitu perencanaan, pelaksanaan, dan evaluasi. Tahap perencanaan dengan memilih tema materi 
pengabdian, narasumber, waktu, penjaringan calon peserta, moderator, dan penyebaran informasi di lingkungan FKIK UMY dan PERMITHA. Tahap pelaksanaan berupa sosialisasi yang disampaikan oleh 4 narasumber, tanya jawab dan diskusi dari peserta pengabdian kepada narasumber. Tahap evaluasi pasca kegiatan pengabdian dengan menggelar diskusi internal antar panitia terhadap pengabdian yang telah dilaksanakan, kemungkinan pengabdian berkelanjutan, kendala yang ditemui, dan penyusunan laporan kegiatan oleh masing-masing pemateri.

Mitra pengabdian adalah mahasiswa Indonesia yang menempuh pendidikan di Thailand yang tergabung dalam PERMITHA (perkumpulan mahasiswa Indonesia di Thailand).

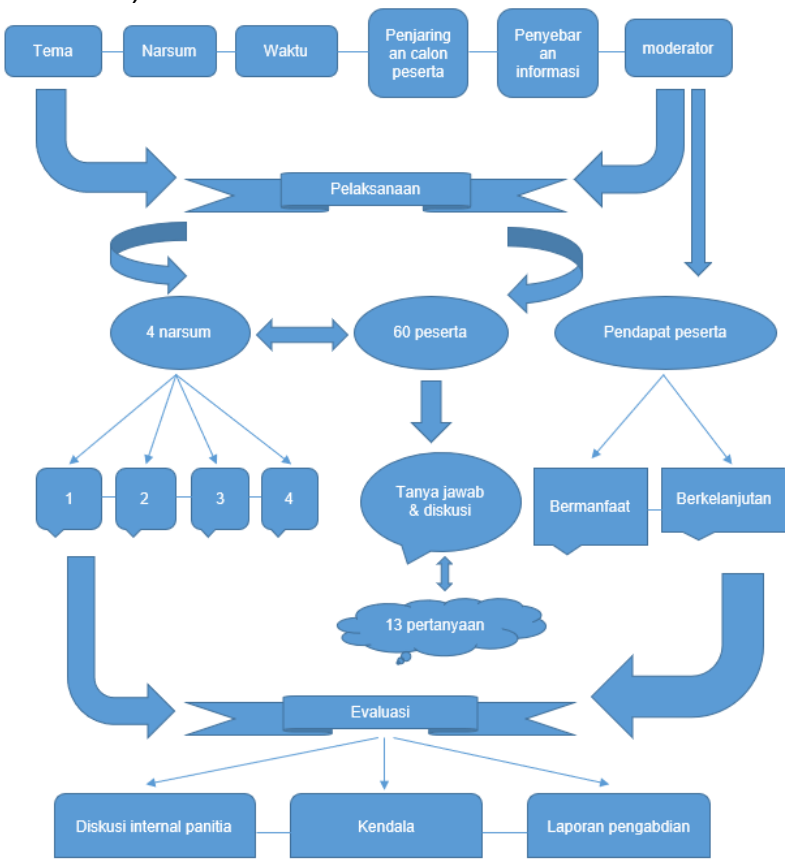

Gambar 1. Metode Pelaksanaan Pengabdian

Gambar 1 menjelaskan tiga tahapan dalam kegiatan pengabdian internasional ini. Pada perencanaan diputuskan mengangkat tema vaksinasi Covid-19 dan HPV yang menyangkut kesehatan reproduksi wanita. Narasumber yang ditunjuk menyesuaikan tema tersebut antara lain: 1. dr. Ivanna Beru Brahmana, SpOG(K), 2. dr. Supriyatiningsih, M.Kes., SpOG, 3. dr. Agus Widiyatmoko, Sp.PD., M.Sc, dan 4. Nur Azizah Indriastuti, S.Kep., Ns., M.Kep., dan sebagai moderator adalah dr. Nova Maryani, MMR., Sp.An., seperti yang tampak pada Gambar 1 di flyer pengabdian.

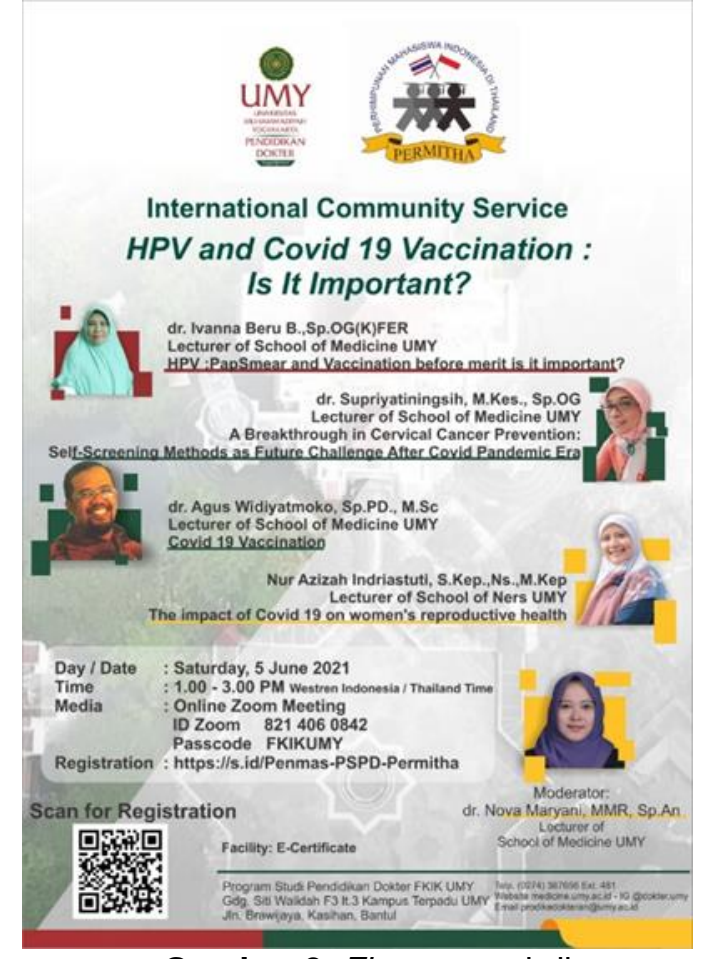

Gambar 2. Flyer pengabdian

Hari Sabtu, 5 Juni 2021 jam 13.0015.00 WIB sebagai waktu pelaksanaan pengabdian, masing-masing narasumber diberikan waktu 20 menit untuk menyampaikan materi. Empat puluh menit waktu yang tersisa digunakan sebagai tanya jawab dan diskusi, serta penyampaian kesimpulan dan pengumuman oleh moderator. Upaya penjaringan peserta pengabdian dan penyebaran informasi segera dilakukan, setelah perencanaan dianggap matang dan disetujui.

Calon peserta dipersilakan mendaftar melalui link: https://s.id/Penmas-PSPDPermitha. Peserta yang sudah mendaftar diberikan link join saat acara berlangsung dan virtual background yang akan dipakai pada saat pelaksanaan pengabdian internasional melalui zoom, seperti tampak pada Gambar 2. Pelaksanaan pengabdian diisi oleh empat narasumber dan dihadiri oleh 60 orang peserta, baik yang berdomisili di wilayah Propinsi Daerah Istimewa Yogyakarta (DIY), luar DIY, dan Thailand. Evaluasi pelaksanaan kegiatan dilakukan saat acara berlangsung dengan cara observasi. 
International Community Service School of Medicine UMY - PERMITHA

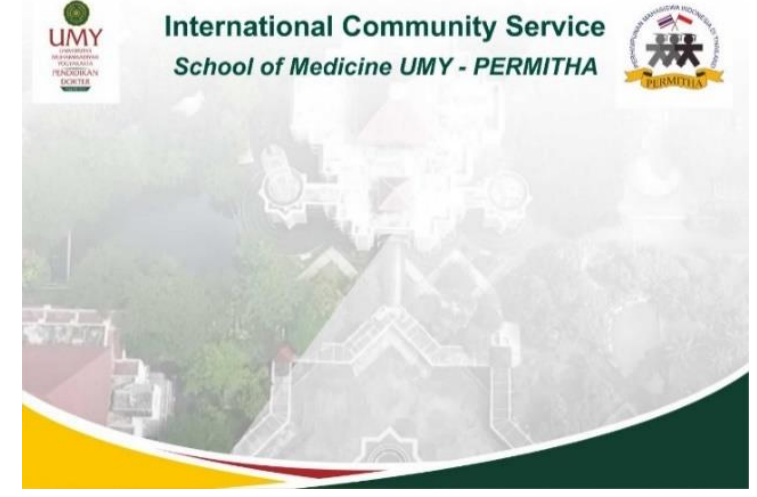

Gambar 3. Virtual background pengabdian internasional

Evaluasi pasca kegiatan pengabdian berupa diskusi internal panitia tentang jalannya pengabdian, kendala yang dihadapi, dan penyampaian untuk pembuatan laporan pengabdian oleh masing-masing narasumber.

\section{HASIL DAN PEMBAHASAN}

Setiap peserta yang bergabung dalam media zoom diminta untuk mengisi daftar hadir untuk mendapatkan e-sertifikat setelah acara berakhir.

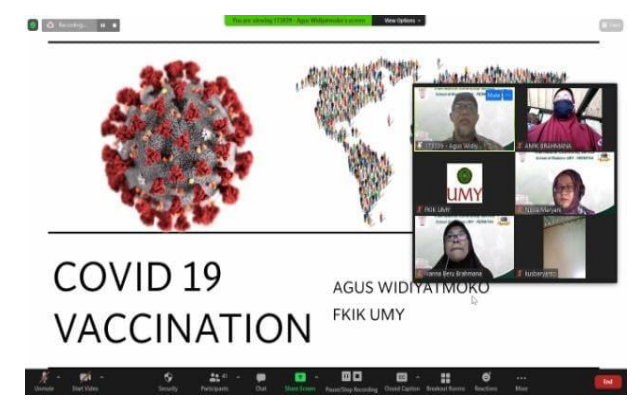

Gambar 4. Presentasi narasumber

Gambar 4 menunjukkan presentasi yang dilakukan oleh narasumber melalui media zoom. Webinar dihadiri oleh 60 orang peserta, baik yang berdomisili di DIY, luar DIY, dan Thailand.

Narasumber pertama adalah dr. Agus Widiyatmoko, Sp.PD., M.Sc menyampaikan materi Covid-19 Vaccination. Vaksinasi diberikan untuk meningkatkan daya tahan tubuh seseorang yang menerima vaksin tersebut, sehingga tidak akan berkembang menjadi suatu penyakit. Efek samping yang mungkin timbul setelah pemberian vaksinasi bervariasi pada penerima vaksin, tergantung kondisi tubuh masing-masing. Manfaat pemberian vaksinasi adalah seandainya penerima vaksin tertular penyakit, gejala yang timbul tidak akan separah mereka yang tidak menjalani vaksinasi.

Narasumber kedua yaitu dr. Ivanna Beru Brahmana, SpOG(K) menyampaikan materi yang berjudul: "IVA and Papsmear examination, vaccination to prevent cervical cancer". Pemeriksaan IVA dan Pap smear merupakan pencegahan sekunder terhadap kanker serviks. Pencegahan primernya berupa pemberian vaksinasi HPV.

Narasumber ketiga yakni dr. Supriyatiningsih, M.Kes., SpOG menyampaikan materi dengan judul: "Breakthrough in Cervical Cancer Prevention: Self-Screening Methods as Future Challenge After Covid Pandemic Era". Pemeriksaan sitologi dianjurkan tiap tiga tahun sekali, dimulai sejak usia 21 tahun. Apabila pemeriksaan Pap smear dilakukan bersamaan dengan pemeriksaan HPV DNA, maka pemeriksaan bisa dilakukan tiap lima tahun sekali, sejak usia 30 tahun. Pemeriksaan untuk skrining kanker serviks secara mandiri diinformasikan dalam materi ini.

Narasumber keempat yaitu Nur Azizah Indriastuti, S.Kep., Ns., M.Kep mengambil judul: "The Impact of Covid-19 on Women's Reproductive Health". Karantina dan social distancing mungkin menimbulkan depresi pada penyintas. Hal ini bisa menyebabkan menurunnya aktifitas seksual mereka. Lockdown dan social distancing menyebabkan sedikitnya ibu hamil yang mendatangi pelayanan ante natal care (ANC). Pelayanan Keluarga Berencana (KB) pun menurun pada kondisi pandemi ini. Kondisi ini menimbulkan kekhawatiran terjadinya banyak kehamilan yang tidak dipersiapkan atau diinginkan. Kekhawatiran terhadap dampak psikologis pada masyarakat akibat pandemi juga menggugah ide dilakukannya pengabdian serupa di Wonogiri. Pengabdian tersebut menyampaikan informasi tentang bagaimana meningkatkan dan mempertahankan imunitas tubuh di masa pandemi, dengan menjaga pola hidup dan pola makan (Mustofa and Suhartatik, 2020).

Tabel 1. Karakteristik Peserta Pengabdian

\begin{tabular}{|c|c|c|c|c|}
\hline $\begin{array}{l}\text { No } \\
\text {. }\end{array}$ & $\begin{array}{l}\text { Karakteris } \\
\text { tik }\end{array}$ & & $\begin{array}{l}\text { Jumlah } \\
(\mathrm{n}=60)\end{array}$ & $\begin{array}{l}\text { Persent } \\
\text { ase (\%) }\end{array}$ \\
\hline \multirow{3}{*}{1.} & \multirow{3}{*}{$\begin{array}{l}\text { Umur } \\
\text { (tahun) }\end{array}$} & $<20$ & 0 & 0 \\
\hline & & $20-35$ & 31 & 51,7 \\
\hline & & $>35$ & 29 & 48,3 \\
\hline \multirow{3}{*}{2.} & \multirow{3}{*}{ Domisili } & DIY & 34 & 56,7 \\
\hline & & $\begin{array}{l}\text { Luar } \\
\text { DIY }\end{array}$ & 15 & 25 \\
\hline & & $\begin{array}{l}\text { Thaila } \\
\text { nd }\end{array}$ & 11 & 18,3 \\
\hline
\end{tabular}

Tabel 1 menunjukkan karakteristik peserta pengabdian internasional. Tidak didapatkan peserta berusia dibawah 20 tahun. Sebagian besar peserta $51,7 \%(31 / 60)$ berusia antar 20 35 tahun, yang merupakan usia reproduksi 
sehat. Peserta pengabdian berusia $>35$ tahun sebanyak 48,3\% (29/60).

Sebagian besar peserta pengabdian berdomisili di DIY yakni sebesar 56,7\% (34/60). Jumlah peserta pengabdian yang berdomisili di luar DIY dan di Thailand tidak terpaut jauh, masing-masing sebesar $25 \% \quad(15 / 60)$ dan $18,3 \%(11 / 60)$. Hal ini berarti bila dibandingkan antara peserta pengabdian yang berdomisili di DIY dibandingkan dengan luar DIY, mempunyai perbandingan yang tidak jauh berbeda, yaitu $56,7 \%$ vs 43,3\%. Hal ini menunjukkan penjaringan peserta pengabdian bisa merata, bahkan yang berdomisili di Thailand pun mempunyai antusiasme menyimak materi pengabdian.

Keminatan para peserta kemungkinan dikarenakan tema yang diangkat oleh panitia sedang menjadi trending topic pada saat ini yaitu mengenai vaksinasi Covid-19. Materi juga membahas tentang kesehatan reproduksi wanita yakni vaksinasi untuk pencegahan kanker serviks. Materi penyuluhan berupa power point disampaikan oleh masing-masing narasumber dengan dipandu oleh moderator, sekaligus mengingatkan alokasi waktu yang tersedia.

Antusiasme peserta tampak dari 13 pertanyaan yang diajukan oleh peserta. Gambar 5 menunjukkan sebagian dari pertanyaan yang disampaikan peserta pengabdian kepada narasumber.

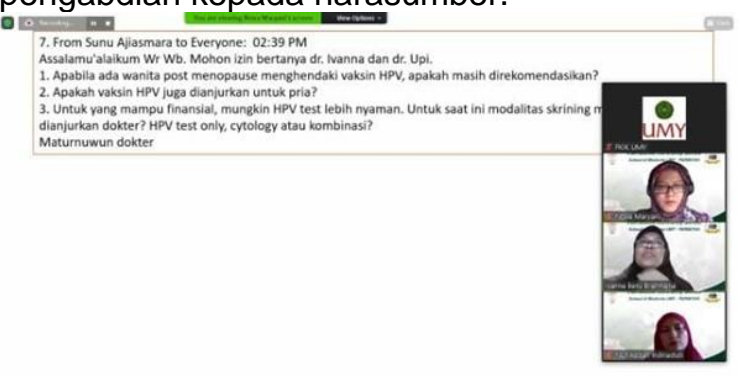

Gambar 5. Pertanyaan Peserta Pengabdian

Tabel 2. Pertanyaan Peserta Pengabdian Internasional

\begin{tabular}{ll}
\hline No. & \multicolumn{3}{c}{ Pertanyaan Peserta } \\
\hline 1. & $\begin{array}{l}\text { Apakah vaksin HPV tetap efektif } \\
\text { dilakukan pada wanita usia 34 tahun? }\end{array}$ \\
\hline 2. & $\begin{array}{l}\text { Pada anak perempuan yang belum } \\
\text { menikah, vaksin HPV mulai bisa } \\
\text { diberikan pada usia berapa? }\end{array}$ \\
\hline 3. & $\begin{array}{l}\text { Bagaimanakah kualitas vaksin yang } \\
\text { beredar di Indonesia? }\end{array}$ \\
\hline 3. & $\begin{array}{l}\text { Bagaimana pendapat narasumber } \\
\text { tentang rencana pemerintah untuk } \\
\text { memulai pembelajaran tatap muka, } \\
\text { apakah sudah aman? }\end{array}$ \\
\hline Apakah vaksinasi HPV perlu diulang \\
lagi setelah beberapa tahun kemudian,
\end{tabular}

\begin{tabular}{ll}
\hline & apabila sudah mendapatkan vaksinasi \\
& HPV sebanyak 3x? \\
\hline 6. & Apakah boleh melakukan suntikan \\
vaksinasi Covid, sedangkan masih \\
punya jadual suntikan hepatitis B yang \\
ketiga?
\end{tabular}

Tabel 2 menampilkan 13 pertanyaan yang diajukan oleh peserta kepada para narasumber. Masing-masing pertanyaan dijawab dengan semangat pula oleh para narasumber yang dituju. Vaksinasi HPV bisa diberikan pada remaja putri mulai berumur 9 tahun, hingga ibu-ibu berusia 45 atau 55 tahun. Hal ini dikarenakan terdapat dua jenis vaksinasi yang beredar di Indonesia. Dengan demikian seorang wanita yang sudah mengalami menopause masih memungkinkan menerima vaksinasi HPV, berdasarkan berapa usia orang tersebut saat ini. Menopause yang sudah terjadi sebelum usia 45 tahun atau 55 tahun, berarti masih diijinkan mendapatkan vaksinasi HPV. Pemberian vaksinasi HPV sebanyak 3x suntikan. Apabila sudah mendapatkan 3x suntikan, maka vaksinasi berlaku seumur hidup, tanpa perlu pengulangan lagi.

Vaksinasi HPV yang dilakukan pada seorang gadis, maka penyuntikan vaksin bisa langsung diberikan, tanpa pemeriksaan Pap smear terlebih dahulu. Bagi wanita yang sudah menikah, maka perlu pemeriksaan Pap smear terlebih dahulu, sebelum pemberian vaksinasi HPV. Hal ini dikarenakan dengan melakukan pemeriksaan Pap smear akan tampak gambaran serviks. Apabila ternyata serviks 
menunjukkan gambaran yang mencurigakan sebagai suatu keganasan, berarti orang tersebut tidak perlu mendapatkan vaksinasi HPV.

Apabila memungkinkan dilakukan secara rutin, maka pemeriksaan kombinasi Pap smear dengan HPV DNA tiap lima tahun sekali akan lebih akurat daripada hanya melakukan pemeriksaan Pap smear saja, atau HPV DNA saja. Vaksinasi HPV juga bisa diberikan pada pria, untuk mencegah timbulnya penyakit kutil kelamin

Pada pengabdian kali ini karena dilakukan secara online, hanya disampaikan informasi bagaimana pentingnya dilakukan pemeriksaan Pap smear secara rutin pada wanita sebagai upaya deteksi dini kanker serviks. Selain itu juga menjelaskan apabila hasil Pap smear normal, maka akan lebih baik bila ditindaklanjuti dengan pemberian vaksinasi HPV, sebagai upaya pencegahan primer terhadap kanker serviks. Hal ini sejalan dengan pengabdian yang dilakukan di Aceh Selatan yang memberikan penyuluhan tentang pemeriksaan Pap smear. Hal yang membedakan adalah metode pengabdian yang digunakan, pada penyuluhan di Aceh Selatan dilakukan secara tatap muka dengan peserta pengabdian (Andika, Safitri and Safira, 2020). Pelaksanaan penyuluhan pemeriksaan Pap smear tanpa dilanjutkan melakukan pemeriksaan Pap smear pada peserta juga menjadi metode pelaksanaan pengabdian di Sokaraja Kulon. Hal yang membedakan adalah pengabdi memberikan demonstrasi teknik pemeriksaan IVA dan Pap smear pada peserta (Riani and Ambarwati, 2020).

Hal berbeda dengan pengabdian yang pernah dilakukan pengabdi, selain memberikan penyuluhan tentang pentingnya pemeriksaan Pap smear dan pemberian vaksinasi HPV, pengabdian dilanjutkan melakukan pemeriksaan Pap smear pada peserta, dan berlanjut dengan pemberian vaksinasi. Dengan demikian secara keseluruhan, pengabdian membutuhkan waktu lebih kurang 1,5 tahun, hingga seluruh peserta pengabdian yang terdaftar vaksinasi HPV sudah lengkap mengikuti penyuntikan $3 x$ vaksinasi (Brahmana, 2021).

Penyuluhan pemeriksaan IVA dan Pap smear dilanjutkan dengan pemeriksaan IVA dan Pap smear pada peserta pengabdian juga dilakukan di Mojokerto. Pada pengabdian tersebut tidak dilanjutkan dengan penyuntikan vaksinasi HPV. Keseluruhan lama waktu pengabdian adalah lima bulan (Nurhayati, 2020). Penyuluhan tentang pemeriksaan Pap smear dilanjutkan dengan pelaksanaan pemeriksaan Pap smear pada peserta pengabdian juga dilakukan di Karanganyar. Pada penagbdian ini tidak dilakukan penyuluhan dan pemeriksaan IVA seperti pengabdian yang dilakukan di Mojokerto (Rosyidah, 2021).

Pengabdian serupa dengan tema pemeriksaan Pap smear, namun mempunyai sasaran peserta pengabdian yang berbeda yaitu tenaga kesehatan, dilakukan di Lampung Utara. Pada pengabdian tersebut pemberian informasi diutamakan pada tenaga kesehatan, oleh karena mereka merupakan ujung tombak yang akan menyebarkan informasi pada masyarakat (Muhartono, Saftarina and Windarti, 2016).

Vaksinasi Covid-19 di Indonesia dilakukan secara bertahap. Oleh karena itu sejauh belum semua masyarakat menerima vaksinasi, tentunya belum semua masyarakat mempunyai daya tahan tubuh yang cukup dalam menghadapi penyakit Covid-19. Dengan demikian masih belum aman apabila akan dilakukan pembelajaran tatap muka. Kekebalan kelompok baru terbentuk apabila cakupan vaksinasi sudah tinggi dan merata di seluruh wilayah Indonesia (Kemenkes RI Dirjen P2P, 2020).

Vaksinasi yang beredar di Indonesia sudah melalui tahapan penelitian yang lengkap, walaupun dalam status emergensi, dengan demikian kualitasnya sama dengan vaksinasi yang sudah ada. Sebelum penyuntikan vaksinasi, setiap calon penerima vaksin akan diperiksa tentang status kesehatannya dan kemungkinan adanya penyakit penyerta. Berdasarkan rekomendasi Perhimpunan Dokter Spesialis Penyakit Dalam Indonesia (PAPDI) sudah terdapat kriteria calon penerima vaksin yang dinilai mempunyai kelayakan menerima vaksinasi Covid-19 ataukah belum layak. Dengan demikian diharapkan calon penerima vaksin bisa lebih tenang dan tidak panik apabila akan menerima vaksinasi Covid-19, oleh karena akan melewati pemeriksaan yang teliti, sebelum pelaksanaan penyuntikan vaksin ('Rekomendasi PAPDI tentang Pemberian Vaksinasi Covid-19', 2020).

Apabila jadual suntikan vaksinasi Covid-19 selesai, maka penerima vaksin bisa melakukan vaksinasi lain, misalkan vaksin Hepatitis B dengan jarak minimal 1 bulan. Bagi peserta yang kebetulan memang mengalami penyuntikan vaksinasi berlanjut dari satu jenis vaksinasi ke jenis vaksinasi lain, yang utama diperhatikan juga kemungkinan rasa takut calon penerima vaksin terhadap jarum suntik. Informasi inipun kemudian ditambahkan bahwa ukuran jarum, kedalaman penyuntikan, dan petugas vaksinator sudah sesuai standar baku dan mereka yang sudah kompeten dalam 
bidangnya. Dengan demikian diharapkan para calon penerima vaksinasi tidak perlu merasa takut yang berlebihan terhadap tindakan penyuntikan vaksinasi. Pengabdian yang mengkhususkan memberikan motivasi "Aku Tidak Takut Disuntik Vaksin Covid-19" telah dilakukan di Tegal (Listina, 2021).

\section{Pendapat Peserta Pengabdian}

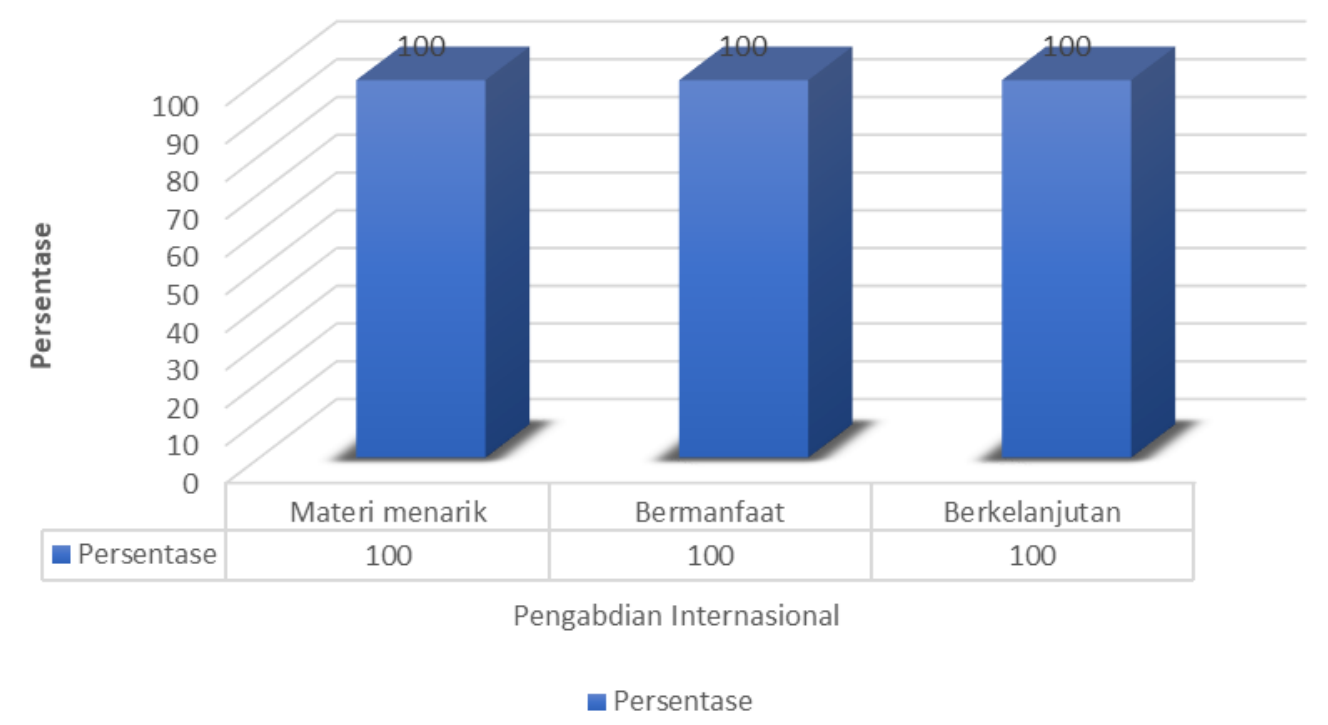

Gambar 6. Pendapat Peserta Pengabdian Internasional

Tahapan evaluasi dilakukan setelah sesi tanya jawab dan diskusi berakhir. Moderator menanyakan kepada para peserta bagaimana pendapat peserta tentang materi pengabdian yang disampaikan, tentang menarik atau tidak dan kemanfaatan. Seluruh peserta pengabdian (100\%) menyatakan materi yang disampaikan narasumber menarik dan bermanfaat. Peningkatan pemahaman peserta dinilai dengan dipahaminya jawaban yang diberikan narasumber terhadap semua pertanyaan yang diajukan. Apabila jawaban yang diberikan sudah memuaskan, dalam hal ini peserta mendapatkan informasi yang lebih daripada sebelum mengikuti webinar.

Adanya kemanfaatan ini, para peserta berharap pengabdian internasional tetap berkelanjutan, dengan mengangkat tema yang tidak kalah menarik. Hal lain juga menunjukkan bahwa dengan webinar, walau tidak bertatap muka, penyampaian materi dapat diterima dengan baik oleh peserta. Secara umum kegiatan pengabdian internasional ini berjalan lancar. Tidak didapatkan kendala selama webinar berlangsung. Pengetahuan peserta pun meningkat setelah menyimak materi pengabdian melalui webinar (Nadilla and Zebua, 2020).

\section{SIMPULAN DAN SARAN}

Pengabdian internasional kerjasama antara FKIK UMY dan PERMITHA memberikan manfaat bagi peserta pengabdian, yaitu meningkatkan pemahaman peserta tentang vaksinasi Covid-19 dan HPV. Pengabdian ini memberikan kesempatan para peserta saling bertukar ilmu, bersilaturahmi, sekaligus melepas rindu kampung halaman. Peningkatan pemahaman peserta didapatkan dari terjawabnya seluruh pertanyaan peserta oleh para narasumber dan peserta merasa puas dengan jawaban yang diberikan. Pengabdian internasional ini dihadiri oleh 60 peserta dengan menampilkan 4 narasumber dengan kepakaran masing-masing. Seluruh peserta (100\%) menyatakan materi menarik dan bermanfaat, serta mengharapkan pengabdian internasional ini tetap bisa berkelanjutan, dengan menampilkan topik lain yang tetap menarik untuk disimak. Saran yang disampaikan adalah diadakannya penelitian dan pengabdian pelaksanaan vaksinasi Covid-19 dan HPV. Selain itu diupayakan pengabdian internasional ini bisa berlanjut dengan mengangkat topik yang selalu menarik, up to date, dan bermanfaat untuk seluruh peserta pengadian. 


\section{UCAPAN TERIMAKASIH}

Terimakasih yang sebesar-besarnya pengabdi sampaikan kepada FKIK UMY dan PERMITHA yang telah menyelenggarakan pengabdian internasional ini.

\section{DAFTAR RUJUKAN}

Alsharji, K. E. (2020) 'Anxiety and depression during the COVID-19 pandemic in Kuwait: the importance of physical activity', Middle East Current Psychiatry, 27(1). doi: 10.1186/s43045-020-000656.

Andika, F., Safitri, F. and Safira, A. (2020) 'Edukasi tentang Pemeriksaan Papsmear pada Wanita Usia Subur di Desa Baharu Kecamatan Susoh', Jurnal Pengabdian Masyarakat (Kesehatan) Universitas Ubudiyah Indonesia, 2(2), pp. 79-83.

Brahmana, I. B. (2021) 'Edukasi Pencegahan Kanker Serviks Secara Primer \& Sekunder Bagi Dosen FKIK UMY', Prosiding Seminar Nasional Program Pengabdian Masyarakat, pp. 644-652. doi: 10.18196/ppm.34.63.

Fisher, J. R. W. and Stocker, R. (2020) 'The Medical Journal of Australia - Pre-print - 10 June 2020 Mental health of people in Australia in the first month of COVID19 restrictions: a national survey', (June).

Kemenkes RI Dirjen P2P (2020) 'Petunjuk Teknis Pelaksanaan Vaksinasi dalam Rangka Penanggulangan Pandemi Corona Virus Disease 2019 (COVID19)', Kementerian Kesehatan RI, 4247608(021), p. 114. Available at: https://www.kemkes.go.id/article/view/ 19093000001/penyakit-jantungpenyebab-kematian-terbanyak-ke-2-diindonesia.html.

Listina, O. C. (2021) 'Edukasi dan Informasi tentang Vaksinasi "Aku Tidak Takut Disuntik Vaksin Covid-19" di Panti Asuhan Zainab Masykuri Kota Tegal', JABI: Jurnal Abdimas Bhakti Indonesia, 2(1), pp. 51-59.

Ma'ruf, A. (2020) 'Sistem Informasi Satu Data Vaksinasi Covid-19', Kementerian Kesehatan Republik Indonesia.

Muhartono, Saftarina, F. and Windarti, I. (2016) 'Pelatihan Deteksi Dini Kanker Serviks Dengan Metode Pap Smear Di Kotabumi Lampung Utara', JPM Ruwa Jurai, 2(1), pp. 5-8.

Mustofa, A. and Suhartatik, N. (2020) 'Meningkatkan Imunitas Tubuh Dalam Menghadapi Pandemi Covid-19 Di Karangtaruna Kedunggupit, Sidoharjo,
Wonogiri, Jawa Tengah', SELAPARANG Jurnal Pengabdian Masyarakat Berkemajuan, 4(1), p. 317. doi: 10.31764/jpmb.v4i1.3100.

Nadilla and Zebua, W. D. A. (2020) 'Edukasi Tindakan Pencegahan Covid-19 di Era Adaptasi Kebiasaan Baru melalui Webinar', Prosiding Seminar Nasional Pengabdian .... Available at: https://jurnal.umj.ac.id/index.php/semn askat/article/view/7995.

Nurhayati, N. (2020) 'Deteksi Dini Ca . Cerviks melalui Metode PAP Smear / IVA dan Pemberian KIE bagi Wanita Usia Subur Warga Desa TambakAgung-', Prosiding Seminar Nasional Abdimas Ma Chung, pp. 340-348.

Rahayu, R. N. (2021) 'Vaksin covid 19 di Indonesia: analisis berita hoax', Intelektiva: Jurnal Ekonomi, Sosial \& Humaniora, 2(07), pp. 39-49.

'Rekomendasi PAPDI tentang Pemberian Vaksinasi Covid-19' (2020) Pengurus Besar Perhimpunan Dokter Spesialis Penyakit Dalam Indonesia.

Riani, E. N. and Ambarwati, D. (2020) 'Early Detection Kanker Serviks Sebagai Upaya Peningkatan Derajat Hidup Perempuan', SELAPARANG Jurnal Pengabdian Masyarakat Berkemajuan, 3(2), pp. 144-146. doi: 10.31764/jpmb.v3i2.1883.

Rosyidah, D. U. (2021) 'Peningkatan Pengetahuan tentang Kanker Leher Rahim dan Deteksi Dini dengan Pemeriksaan Pap smear', Jurnal Pengabdian Masyarakat Medika, 1(1), pp. 12-16. doi: 10.23917/jpmm.v1i1.266.

Ustun, G. (2021) 'Determining depression and related factors in a society affected by COVID-19 pandemic', International Journal of Social Psychiatry, 67(1), pp. 54-63. doi: $10.1177 / 0020764020938807$. 